UDC 543.4:542.61:546.812

\title{
NEW SIMPLE AND RAPID SPECTROPHOTOMETRIC METHODS FOR THE DETERMINATION OF TRACE LEVEL GOLD(III) USING 2,2',3,4-TETRAHYDROXY-3' - SULPHO-5'-CHLORAZOBENZENE PRESENCE OF THE CATIONIC SURFACTANTS
}

\author{
P.R.Mammadov \\ Baku State University \\ poladazer@gmail.com \\ Received 05.03.2019 \\ Accepted 22.08.2019
}

\begin{abstract}
It is shown that gold(III) with 2,2',3,4-tetrahydroxy-3'-sulpho-5'-chlorazobenzene (TSXAB) the rapid reacts in $\mathrm{pH} \mathrm{5-6}$ acidic solution to form brownish-yellow complex and in $\mathrm{pH} \mathrm{4-5}$ acidic solution to form brownish complexes in the presence of the cationic surfactants - cetylpyridinium chloride $(\mathrm{CPCl})$, cetylpyridinium bromide $(\mathrm{CPBr})$ and cetyltrymethylammonium bromide (CTMABr). The absorption spectra of the Au(III)-TSXAB system is a curve with the maximum absorbance at $490 \mathrm{~nm}$ and molar absorption coefficient of $2.310^{4} 1 \mathrm{~mol}^{-1} \mathrm{~cm}^{-1}$ in aqueous media. The absorption spectra of the Au(III)-TSXAB$\mathrm{CPCl}, \mathrm{Au}(\mathrm{III})-\mathrm{TSXAB}-\mathrm{CPBr}$ and $\mathrm{Au}(\mathrm{III})-\mathrm{TSXAB}-\mathrm{CTMABr}$ systems is a curves with the maximum absorbances at 520, 520 and $540 \mathrm{~nm}$ and molar absorption coefficients of $3.78 \cdot 10^{4}, 3.67 \cdot 10^{4}$ and $3.81 \cdot 10^{4}$ $1 \mathrm{~mol}^{-1} \mathrm{~cm}^{-1}$ in micellar media respectively. The absorbance was linear for $0.584-5.61 \mathrm{mkg} / \mathrm{ml} \mathrm{of} \mathrm{Au}$ (III) in the Au(III)-TSXAB-CPCl, Au(III)-TSXAB system and 0.428-6.362, 0.435-6.221, 0.436-6.832 mkg/ml of $\mathrm{Au}$ (III) in the $\mathrm{Au}(\mathrm{III})-\mathrm{TSXAB}-\mathrm{CPCl}, \mathrm{Au}(\mathrm{III})-\mathrm{TSXAB}-\mathrm{CPBr}$ and $\mathrm{Au}(\mathrm{III})-\mathrm{TSXAB}-\mathrm{CTMABr}$ systems, respectively. The Sandell's sensitivity for $\mathrm{Au}(\mathrm{III})$ were found to be $7 \mathrm{mkg} \mathrm{cm}^{-2}$ in $\mathrm{Au}(\mathrm{III})-\mathrm{TSXAB}$ system and $5,6,5 \mathrm{mkg} / \mathrm{cm}$ in the $\mathrm{Au}(\mathrm{III})-\mathrm{TSXAB}-\mathrm{CPCl}, \mathrm{Au}(\mathrm{III})-\mathrm{TSXAB}-\mathrm{CPBr}, \mathrm{Au}(\mathrm{III})-\mathrm{TSXAB}-\mathrm{CTMABr}$ systems. The proposed methods was successfully used in the determination of Au(III) in several synthetic mixtures. The relative standard deviation $(n=5)$ was $(0-2.0) \%$, for $\mathrm{Au}(\mathrm{III})$ indicating that this methods are highly precise and reproducible. The results obtained agree well with synthetic mixture samples analyzed by inductively coupled plasma optical emission spectrometry.
\end{abstract}

Keywords: spectrophotometric, Au(III), determination, 2,2',3,4-tetrahydroxy-3'-sulpho-5'-chlorazobenzene, cationic surfactants.

\section{doi.org/10.32737/0005-2531-2020-1-20-25}

\section{Introduction}

The large amounts of gold are still used in the manufacture of coins, medals, jewelry, art and also has a number of uses in industry, medicine, and other fields [1]. Therefore, it is clear that in the arsenal of analysts there must be simple and rapid methods to determine $A u(I I I)$ in a wide concentration range with the highest possible sensitivity accuracy. Although many modern techniques, such as inductively coupled plasma atomic emission spectrometry (ICP-AES) [2], inductively coupled plasma mass spectrometry (ICP-MS) [3, 4], electrothermal atomic absorption spectrophotometry (EAAS) [5, 6], graphite furnace atomic absorption spectrophotometry (GFAAS) [7] are available for the determination of silver at trace levels in numerous complex materials.

Factors such as the low cost of instrument, technical know-how, consumable and costly maintenance of technique restrict the wider applicability of these techniques, particularly in laborato- ries with limited budget in developing countries and for field work lack of any requirement for consumables and almost no maintenance, have caused spectrophotometric methods to remain a popular technique. The wide variety of spectrophotometric methods for determination of $\mathrm{Au}$ (III) have been reported, each chromogenic system has its advantages and disadvantages with respect to sensitivity, selectivity and convenience [8-12]. The azocompounds on the basis of pyroghallol had widely been applied for the determination of noble metal ions, this type of reagent has higher sensitivity and high selectivity [13]. In the search for more sensitive azocompounds on the base of pyroghallol reagent, in this work, a reagent 2,2',3,4-tetrahydroxy-3'-sulpho5 '-chlorazobenzene (TSXAB) was synthesized according to the method of [13] and a color reaction of TSXAB with $\mathrm{Au}$ (III) in aqueous and in the presence of the cationic surfactants was carefully studied. The aim of present study is to develop a simple direct spectrophotometric method 
for the trace determination of Au with TSXAB in aqueous solutions, and in the presence of cationic surfactants, such as cetylpyridinium chloride, cetylpyridine bromide and cetyltrimethylammonium bromide in aqueous solutions.

\section{Experimental part}

\section{Instrumentation}

The absorbance of solutions was measured with a Perkin Elmer (United States) (Model: Lambda-40) double-beam UV/VIS spectrophotometer and with a KFK-2 photoelectrocolorimeter (Russia), with $1 \mathrm{~cm}$ matched quartz cells.

The $\mathrm{pH}$ values of solutions was controlled on the Ionomer İ-121 (Russia) with glass electrode customized by standart bufer solutions.

A Perkin Elmer (United States) (Model: Optima-2100DV) Inductively Coupled Plasma Optical Emission Spectrometer (ICP-OES) was used for comparing the results.

\section{Standard solutions}

A $10^{-2}$ M $100 \mathrm{ml}$ standard solution of $\mathrm{Au}$ was prepared by dissolving $1.967 \mathrm{~g}$ of $\mathrm{Au}$ (purity $99.99 \%$ ) in aqua regia by warming, evaporating the solution to dryness, dissolving the residue in hydrochloric acid, evaporating the solution to half its volume, cooling and diluting with water to $100 \mathrm{ml}$ in calibrated flask. Working solutions were prepared by appropriate dilution of standard solution. The gravimetric method (using hydrogen peroxide) was used for controlling of gold(III) concentration in the standard solution [1].

2,2',3,4-tetrahydroxy-3'-sulpho-5'-chlorazobenzene (TSXAB) $\left(2 \cdot 10^{-3} \mathrm{M}\right)$. The reagent was synthesized according to the method [13]. The solution was prepared by dissolving the requisite amount of TSXAB in a known volume of distilled water and ethanol (1:1). More dilute solution of the reagent was prepared as required.

Cationic surface-active substances (CSAS). $1 \cdot 10^{-2} \mathrm{M}$ cationic surface-active substances (surfactants) - cetylpyridine chloride $(\mathrm{CPCl})$, cetylpyridine bromide $(\mathrm{CPBr})$ and cetyltrymethylammonium bromide (CTMABr) was preparing by dissolving the requisite amounts of surfactants in distilled water.

Aqueous ammonia solution. A $100 \mathrm{ml}$ solution of aqueous ammonia was prepared by diluting $10 \mathrm{~mL}$ of concentrated $\mathrm{NH}_{3}$ (28\%$30 \%$ ) ACS grade with distilled water. The solution was stored in a glass bottle.

EDTA solution. A $100 \mathrm{ml}$ stock solution of EDTA $(0.1 \% \mathrm{w} / \mathrm{v})$ was prepared by dissolving $128 \mathrm{mg}$ of ethylenediaminetetraacetic acid, disodium salt dehydrate in $100 \mathrm{ml}$ distilled water.

Other solutions. Solutions of a large number of inorganic ions and complexing agents were prepared from their grade, or equivalent grade, water soluble salts.

\section{Results and discussion}

$\mathrm{Au}(\mathrm{III})$ with 2,2',3,4-tetrahydroxy-3'sulpho-5'-chlorazobenzene rapidly reacts in $\mathrm{pH}$ 5-6 acidic solution to form brownish-yellow complex and in $\mathrm{pH} 4-5$ acidic solution to form brownish complexes in presence of the cationic surfactants.

Absorption spectra. The absorption spectra of the $\mathrm{Au}(\mathrm{III})-\mathrm{TSXAB}-$ is a curve with the maximum absorbance at $490 \mathrm{~nm}$ and an average molar absorption coefficient of $2.3 \cdot 10^{4} 1$ $\mathrm{mol}^{-1} \mathrm{~cm}^{-1}$ in aqueous media. The absorption spectra of the $\mathrm{Au}(\mathrm{III})-\mathrm{TSXAB}-\mathrm{CPCl}, \mathrm{Au}(\mathrm{III})-$ TSXAB-CPBr and Au(III)-TSXAB-CTMABr systems is a curve with the maximum absorbances at 520, 520 and $540 \mathrm{~nm}$ and average molar absorption coefficients of $3.78 \cdot 10^{4}, 3.67 \cdot 10^{4}$ and $3.81 \cdot 10^{4} 1 \mathrm{~mol}^{-1} \mathrm{~cm}^{-1}$ in micellar media, respectively (Figure).

Effect of acidity. Of the various $\mathrm{pH} \quad 0-12$ studied, $\mathrm{pH}$ 5.0-6.0 found to be the best acid environment for the $\mathrm{Au}(\mathrm{III})-\mathrm{TSXAB}$ system and $\mathrm{pH}$ 4.0-5.0 for the $\mathrm{Au}(\mathrm{III})-\mathrm{TSXAB}-\mathrm{CPCl}, \mathrm{Au}(\mathrm{III})-$ TSXAB-CPBr and $\mathrm{Au}(\mathrm{III})-\mathrm{TSXAB}-\mathrm{CTMABr}$ systems at room temperature $(25 \pm 5)^{0} \mathrm{C}$. The absorbance of the reagent solution and the all systems depends on the medium $\mathrm{pH}$; therefore, the absorption spectra are studied relatively to a blank experiment against the background of control experiment ( $\mathrm{R}$ and $\mathrm{R}+\mathrm{CSAS}$ ), which was prepared in the same conditions.

Effect of time. The reaction is fast. Constant maximum absorbance was obtained after 10 min for $\mathrm{Au}(\mathrm{III})-\mathrm{TSXAB}$ system in aqueous media and $5 \mathrm{~min}$ for $\mathrm{Au}(\mathrm{III})-\mathrm{TSXAB}-\mathrm{CPCl}$, $\mathrm{Au}(\mathrm{III})-\mathrm{TSX} A \mathrm{~B}-\mathrm{CPBr}$ and $\mathrm{Au}(\mathrm{III})-\mathrm{TSXAB}-$ CTMABr systems in micellar media, respectively. 


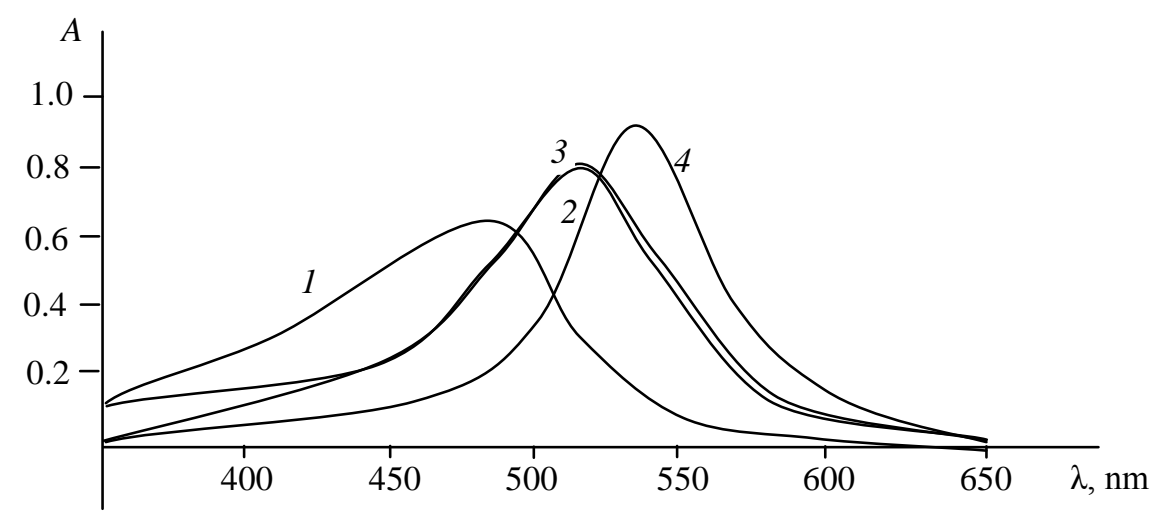

Absorption spectra of $\mathrm{Au}(\mathrm{III})-\mathrm{TSXAB}(1), \mathrm{Au}(\mathrm{III})-\mathrm{TSXAB}-\mathrm{CPCl}$ (2), $\mathrm{Au}(\mathrm{III})-\mathrm{TSXAB}-\mathrm{CPBr}$

(3) and Au(III)-TSXAB-CTMABr (4).

Effect of temperature. The absorbance at different temperatures, $0-80^{\circ} \mathrm{C}$, of a $25 \mathrm{ml}$ solution of all systems was measured according to the standard procedure. The absorbance was found to be strictly unaltered through-out the temperature range of $10-40^{\circ} \mathrm{C}$. Therefore, all measurements were performed at room temperature $(25 \pm 5)^{0} \mathrm{C}$.

Stoichiometry. The component ratio in the complexes was found using the method of isomolar series, the Starik and Barbanel relative yield method and the equilibrium shift method. All the methods showed that the component ratio were 1:2 in the double $\mathrm{Au}(\mathrm{III})-\mathrm{TSXAB}$ system and $1: 2: 2$ in the triple $\mathrm{Au}(\mathrm{III})-\mathrm{TSXAB}-\mathrm{CPCl}$, $\mathrm{Au}(\mathrm{III})-\mathrm{TSXAB}-\mathrm{CPBr}, \quad \mathrm{Au}(\mathrm{III})-\mathrm{TSXAB}-$ CTMABr systems. The number of protons displaced upon complexation was determined by the Astakhovs method, and the indicated component ratio in the complexes was confirmed [14].

Effect of the reagent and cationic surfactants concentration. Different molar excesses of TSXAB and cationic surfactants were added to a fixed $\mathrm{Au}(\mathrm{III})$ concentration and the absorbance was measured according to the standard procedure. It was observed that a $1 \mathrm{mkg} / \mathrm{ml}$ of silver metal (optical path $1 \mathrm{~cm}$ in length), the reagent and cationic surfactants molar ratios produced a constant absorbance of $\mathrm{Au}(\mathrm{III})-\mathrm{TSXAB}-\mathrm{CPCl}$, $\mathrm{Au}(\mathrm{III})-\mathrm{TSXAB}-\mathrm{CPBr}, \quad \mathrm{Au}(\mathrm{III})-\mathrm{TSXAB}-$ $\mathrm{CTMABr}$ systems. For all subsequent measurements, $2 \mathrm{ml}$ of $2 \cdot 10^{-4} \mathrm{M}$ TSXAB reagent and $4 \mathrm{ml}$ of $2 \cdot 10^{-4} \mathrm{M}$ cationic surfactants was added.

\section{Analytical performance of the methods}

Calibration graph. The effect of metal concentration was studied in the range of 0.01$100 \mathrm{mkg} / \mathrm{ml}$, distributed in four different sets $(0.01-0.1,0.1-1,1-10 \mathrm{mkg} / \mathrm{ml})$ for convenience of the measurement. The absorbance was linear for $0.584-5.61 \mathrm{mkg} / \mathrm{ml}$ of $\mathrm{Au}(\mathrm{III})$ in the $\mathrm{Au}(\mathrm{III})-\mathrm{TSXAB}$ system and $0.428-6.362$ $\mathrm{mkg} / \mathrm{ml}, \quad 0.435-6.221 \mathrm{mkg} / \mathrm{ml}, \quad 0.436-6.832$ $\mathrm{mkg} / \mathrm{ml}$ of $\mathrm{Au}(\mathrm{III})$ in the $\mathrm{Au}(\mathrm{III})-\mathrm{TSXAB}-$ $\mathrm{CPCl}, \quad \mathrm{Au}(\mathrm{III})-\mathrm{TSXAB}-\mathrm{CPBr}, \quad \mathrm{Au}(\mathrm{III})-$ TSXAB-CTMABr systems respectively. From the slope of the calibration graph, the average molar absorption coefficient was found to be $2.310^{4}$ $1 \mathrm{~mol}^{-1} \mathrm{~cm}^{-1}$ for $\mathrm{Au}(\mathrm{III})-\mathrm{TSXAB}$ system and $3.78 \cdot 10^{4} 1 \mathrm{~mol}^{-1} \mathrm{~cm}^{-1}, 3.67 \cdot 10^{4} 1 \mathrm{~mol}^{-1} \mathrm{~cm}^{-1}$ and $3.81 \cdot 10^{4} 1 \mathrm{~mol}^{-1} \mathrm{~cm}^{-1}$ in the Au(III)-TSXAB$\mathrm{CPCl}, \quad \mathrm{Au}(\mathrm{III})-\mathrm{TSXAB}-\mathrm{CPBr}, \quad \mathrm{Au}(\mathrm{III})-$ TSXAB-CTMABr systems respectively. The selected analytical parameters obtained as a result of the optimization experiments are summarized in Table 1.

Precision and accuracy. The precision of the present method was evaluated by determining different concentrations of $\mathrm{Au}$ (each analyzed at least five times). The relative standard deviation $(n=5)$ was $(0-2.0) \%$, for $0.1-8 \mathrm{mkg}$ of $\mathrm{Au}(\mathrm{III})$, indicating that this method is highly precise and reproducible. The Sandell's sensitivity for $\mathrm{Au}$ (III) made up $7 \mathrm{mkg} / \mathrm{cm}^{-2}$ in $\mathrm{Au}(\mathrm{III})-$ TSXAB system and $5 \mathrm{mkg} \mathrm{cm}^{-2}, 6 \mathrm{mkg} \mathrm{cm}^{-2}, 5$ $\mathrm{mkg} \mathrm{cm} \mathrm{cm}^{-2}$ in the Au(III)-TSXAB- CPCl, $\mathrm{Au}$ (III)-TSXAB-CPBr, $\mathrm{Au}(\mathrm{III})-\mathrm{TSXAB}-$ CTMABr systems respectively. 
Effect of foreign ions. The effect of over 30 cations, anions and complexing agents on the determination of only $1 \mathrm{mkg} / \mathrm{ml}$ of $\mathrm{Au}(\mathrm{III})$ was studied. The criterion for interference was an absorbance value varying by more than $5 \%$ from the expected value for $\mathrm{Au}(\mathrm{III})$ alone. The results are given in Table 2.

Table 1. Selected analytical parameters obtained by optimization experiments

\begin{tabular}{|c|c|c|c|c|c|}
\hline \multirow[b]{2}{*}{ Parameters } & \multirow[b]{2}{*}{$\begin{array}{l}\text { Studied } \\
\text { range }\end{array}$} & \multicolumn{4}{|c|}{ Selected value } \\
\hline & & $\begin{array}{l}\mathrm{Au}(\mathrm{III})- \\
\mathrm{TSXAB}\end{array}$ & $\begin{array}{c}\mathrm{Au}(\mathrm{III})-\mathrm{TSX} A B- \\
\mathrm{CPCl}\end{array}$ & $\begin{array}{l}\mathrm{Au}(\mathrm{III})-\mathrm{TSXAB}- \\
\mathrm{CPBr}\end{array}$ & $\begin{array}{l}\mathrm{Au}(\mathrm{III})-\mathrm{TSXAB}- \\
\text { CTMABr }\end{array}$ \\
\hline Wavelength $/ \lambda_{\max }, \mathrm{nm}$ & $200-800$ & 490 & 520 & 520 & 540 \\
\hline Wavelength $/ \lambda_{\text {opt }}, \mathrm{nm}$ & - & 490 & 540 & 540 & 540 \\
\hline $\mathrm{pH}$ & $0-12$ & $5-6$ & $4-5$ & $4-5$ & $4-5$ \\
\hline Time, $\mathrm{h}$ & $1-24 h$ & $5-10 \mathrm{~min}$ & $5-6 \mathrm{~min}$ & $5-6 \mathrm{~min}$ & $5-6 \mathrm{~min}$ \\
\hline Temperature, ${ }^{0} \mathrm{C}$ & $0-80^{\circ} \mathrm{C}$ & $25 \pm 5^{\circ} \mathrm{C}$ & $25 \pm 5^{\circ} \mathrm{C}$ & $25 \pm 5^{\circ} \mathrm{C}$ & $25 \pm 5^{\circ} \mathrm{C}$ \\
\hline $\mathrm{Au}(\mathrm{III}): \mathrm{TSXAB}: \mathrm{CSAS}$ & $1: 10-10: 1$ & $1: 2$ & $1: 2: 2$ & $1: 2: 2$ & $1: 2: 2$ \\
\hline $\begin{array}{l}\text { Molar absorption coefficient, } \\
1 \mathrm{~mol}^{-1} \mathrm{~cm}^{-1}\end{array}$ & - & $2.30 \cdot 10^{4}$ & $3.78 \cdot 10^{4}$ & $3.67 \cdot 10^{4}$ & $3.81 \cdot 10^{4}$ \\
\hline Linear range/mkg $1^{-1}$ & $0.01-10$ & $0.584-5.61$ & $0.428-6.362$ & $0.435-6.221$ & $0.436-6.832$ \\
\hline $\lg \beta$ & - & 8.58 & 11.58 & 11.26 & 12.88 \\
\hline Sandell's sensitivity/mkg cm${ }^{-2}$ & $0.1-10$ & 7 & 5 & 6 & 5 \\
\hline Relative Standard & $0-5$ & $0-2$ & $0-2$ & $0-2$ & $0-2$ \\
\hline
\end{tabular}

Table 2. Tolerance limits of foreign ions,tolerance ratio [lons $(\mathrm{x})] / \mathrm{Au}(\mathrm{w} / \mathrm{w})$

\begin{tabular}{|c|c|c|c|c|c|}
\hline Ions $x$ & $\mathrm{Au}(\mathrm{III})-\mathrm{TSXAB}$ & $\mathrm{Au}(\mathrm{III})-\mathrm{TSXAB}-\mathrm{CPCl}$ & $\mathrm{Au}(\mathrm{III})-\mathrm{TSXAB}-\mathrm{CPBr}$ & Au(III)-TSXAB-CTMABr & {$[12]$} \\
\hline $\mathrm{Na}(\mathrm{I})$ & 100 & 110 & 115 & 150 & 100 \\
\hline $\mathrm{K}(\mathrm{I})$ & 100 & 145 & 150 & 180 & 100 \\
\hline $\mathrm{Mg}(\mathrm{II})$ & 120 & 160 & 160 & 180 & 100 \\
\hline $\mathrm{Ca}(\mathrm{II})$ & 120 & 170 & 170 & 180 & 100 \\
\hline $\mathrm{Cr}(\mathrm{III})$ & 120 & 175 & 175 & 185 & 100 \\
\hline $\mathrm{Fe}(\mathrm{III})$ & 30 & 45 & 45 & 55 & 25 \\
\hline $\mathrm{Cu}(\mathrm{II})$ & 60 & 80 & 80 & 95 & 50 \\
\hline $\mathrm{Cd}(\mathrm{II})$ & 100 & 130 & 130 & 140 & 100 \\
\hline $\mathrm{Hg}(\mathrm{II})$ & 105 & 145 & 145 & 160 & 100 \\
\hline $\mathrm{Mo}(\mathrm{II})$ & 105 & 135 & 145 & 160 & 100 \\
\hline $\mathrm{Co}(\mathrm{III})$ & 110 & 150 & 150 & 165 & 100 \\
\hline $\mathrm{Zn}(\mathrm{II})$ & 115 & 140 & 150 & 160 & 100 \\
\hline $\mathrm{Be}(\mathrm{III})$ & 110 & 150 & 150 & 155 & 100 \\
\hline $\mathrm{Sn}(\mathrm{IV})$ & 25 & 35 & 35 & 40 & 25 \\
\hline $\mathrm{Mn}(\mathrm{II})$ & 120 & 155 & 155 & 155 & 100 \\
\hline $\mathrm{V}(\mathrm{V})$ & 30 & 50 & 50 & 60 & 25 \\
\hline $\operatorname{Ag}(\mathrm{I})$ & 25 & 45 & 45 & 45 & 25 \\
\hline Ga(III) & 100 & 120 & 120 & 130 & 100 \\
\hline $\mathrm{La}(\mathrm{III})$ & 110 & 140 & 140 & 150 & 100 \\
\hline $\mathrm{Ta}(\mathrm{IV})$ & \begin{tabular}{|l|}
110 \\
\end{tabular} & 140 & 140 & 150 & 100 \\
\hline $\mathrm{Ni}(\mathrm{II})$ & 120 & 155 & 155 & 165 & 100 \\
\hline $\mathrm{Pb}(\mathrm{II})$ & 25 & 35 & 35 & 45 & 25 \\
\hline $\mathrm{NO}_{3}^{-}$ & 250 & 270 & 270 & 285 & 200 \\
\hline $\mathrm{SO}_{4}^{2-}$ & 110 & 1250 & 1250 & 1250 & 1000 \\
\hline $\mathrm{Cl}^{-}$ & 1150 & 1220 & 1220 & 1240 & 1000 \\
\hline $\mathrm{F}^{-}$ & 120 & 125 & 135 & 145 & 100 \\
\hline $\mathrm{HCO}_{3}^{-}$ & 130 & 145 & 155 & 170 & 100 \\
\hline $\mathrm{C}_{2} \mathrm{O}_{4}^{2-}$ & 1100 & 1140 & 1140 & 1250 & 1000 \\
\hline EDTA & 650 & 730 & 760 & 780 & 500 \\
\hline $\mathrm{C}_{4} \mathrm{H}_{4} \mathrm{O}_{6}^{2-}$ & 260 & 280 & 280 & 300 & 200 \\
\hline $\mathrm{CH}_{3} \mathrm{COO}^{-}$ & 110 & 130 & 130 & 140 & 75 \\
\hline
\end{tabular}


Table 3. Determination of $\mathrm{Au}(\mathrm{III})$ in synthetic mixtures

\begin{tabular}{|c|c|c|c|c|c|c|}
\hline \multirow{3}{*}{ Sample } & \multirow{3}{*}{$\begin{array}{l}\text { Composition of mixture } \\
\qquad(\mathrm{mkq} / \mathrm{ml})\end{array}$} & \multicolumn{3}{|c|}{ Proposed method } & \multicolumn{2}{|c|}{ ICP-OES } \\
\hline & & \multicolumn{2}{|c|}{$\mathrm{Au}(\mathrm{III}) \mathrm{mkq} / \mathrm{ml}$} & \multirow{2}{*}{$\begin{array}{c}\text { Recovery } \pm \mathrm{s}^{\mathrm{b}} \\
(\%)\end{array}$} & \multirow{2}{*}{$\frac{\mathrm{Au}(\mathrm{III}) \mathrm{mkq} / \mathrm{ml}}{\text { Found }}$} & \multirow{2}{*}{$\begin{array}{c}\text { Recovery } \pm s \\
(\%)\end{array}$} \\
\hline & & Added & Found $^{\mathrm{a}}$ & & & \\
\hline \multirow[b]{2}{*}{ A } & \multirow{2}{*}{$\mathrm{Au}^{3+}$} & 1.5 & 1.52 & $102 \pm 0.3$ & 1.51 & $101 \pm 0.3$ \\
\hline & & 2.0 & 2.04 & $104 \pm 0.2$ & 2.02 & $102 \pm 0.2$ \\
\hline \multirow{2}{*}{ B } & \multirow{2}{*}{$\mathrm{As}$ in $\mathrm{A}+\mathrm{Cu}^{2+}(25)+\mathrm{Fe}^{3+}(25)$} & 1.5 & 0.51 & $101 \pm 0.4$ & 0.52 & $102 \pm 0.4$ \\
\hline & & 2.0 & 2.03 & $103 \pm 0.2$ & 2.02 & $102 \pm 0.2$ \\
\hline \multirow{2}{*}{$\mathrm{C}$} & \multirow{2}{*}{ As in $\mathrm{B}+\mathrm{Mg}^{2+}(25)+\mathrm{Co}^{3+}(25)$} & 1.5 & 1.51 & $101 \pm 0.2$ & 1.50 & $100 \pm 0.2$ \\
\hline & & 2.0 & 2.02 & $102 \pm 0.2$ & 2.01 & $101 \pm 0.2$ \\
\hline \multirow{2}{*}{$\mathrm{D}$} & \multirow{2}{*}{$\mathrm{As}$ in $\mathrm{C}+\mathrm{Cr}^{3+}(25)+\mathrm{Ca}^{2+}(25)$} & 1.5 & 1.49 & $98 \pm 0.2$ & 1.495 & $99 \pm 0.1$ \\
\hline & & 2.0 & 2.02 & $102 \pm 0.1$ & 2.025 & $101 \pm 0.1$ \\
\hline \multirow{2}{*}{$\mathrm{E}$} & \multirow{2}{*}{ As in $\mathrm{D}+\mathrm{Ag}^{+}(25)+\mathrm{Hg}_{2}^{2+}(25)$} & 1.5 & 1.48 & $97 \pm 0.3$ & 1.49 & $97 \pm 0.3$ \\
\hline & & 2.0 & 2.02 & $102 \pm 0.2$ & 2.01 & $101 \pm 0.2$ \\
\hline
\end{tabular}

${ }^{a}$ Average of five analysis of each sample; ${ }^{b}$ The measure of precision is the standard deviation $(s)$.

\section{Applications}

The Au(III)-TSXAB-CTMABr system was successfully applied to the determination of $\mathrm{Au}(\mathrm{III})$ in a series of synthetic mixtures of various compositions (Table 3 ).

Determination of $\mathrm{Au}(\mathrm{III})$ in synthetic mixtures. Several synthetic mixtures of varyious compositions containing $\mathrm{Au}(\mathrm{III})$ and diverse ions of known concentrations were determined by the present method using EDTA as a masking agent; the results were found to be highly reproducible. The results of synthetic mixtures analysis by the spectrophotometric method were found to be in excellent agreement with those obtained by ICP-OES. The results are given in Table 3. Accurate recoveries were achieved in all solutions.

\section{General Procedure}

To synthetic mixtures samples of varyious compositions containing $1-2 \mathrm{mkg} / \mathrm{ml} \mathrm{Au}(\mathrm{III})$ in $25 \mathrm{ml}$ volumetric flask was mixed with $2 \mathrm{ml}$ of $2 \cdot 10^{-4} \mathrm{M}$ TSXAB reagent solution and $4 \mathrm{ml}$ of $2 \cdot 10^{-4}$ CTMABr solution with subsequent followed by the addition of $5 \mathrm{ml}$ initial solution of EDTA (0.1mass.\% w/v). The mixture was diluted up to the mark with $\mathrm{pH} 5$ buffer solutions. After 5 min the absorbance was measured at 540 $\mathrm{nm}$ against the background of the corresponding reagent. The gold(III) content in the synthetic mixtures sample was determined using a concurrently prepared calibration graph.

\section{Conclusion}

In the present work, a simple, rapid, sensitive and selective methods was developed for the determination of $\mathrm{Au}(\mathrm{III})$ ) in difficult sample matrices. Therefore, this methods can be successful- ly applied to the monitoring of trace amounts of $\mathrm{Au}(\mathrm{III})$ in industrial and natural samples.

\section{References}

1. Busev A.I., Ivanov V.M. Analiticheskaia himiia zolota. M.: Nauka, 1973. 263 s.

2. Steharnik M., Todorović M., Manojlović D. Determination of trace elements in refined gold samples by inductively coupled plasma atomic emission spectrometry. J. Serb. Chem. Soc. 2013. No 7. P. 565-577.

3. Yim S., Choi M., Chae J. Direct determination of gold in rock samples using collision cell quadrupole ICP-MS. J. Am. Soc. Mass Spectrom.. 2012. № 1. P. 17117-8.

4. Juvonen R., Lakomaa T., Soikkeli L. 2002. Determination of $\mathrm{Au}$ and the platinum group elements in geological samples by ICP-MS after nickel sulphide fi re assay: difficulties encountered with different types of geological samples. Talanta. 58:595-603.

5. Jiang W., Z., Hu B., Duan J. Electrothermal vaporization inductively coupled plasma atomic emission spectrometry for the determination of $\mathrm{Au}$, palladium, and platinum using chelating resin YPA4 as both extractant and chemical modifier. Talanta. 2004. 63: P. 585-292.

6. Medved J., Bujdos M., Matús P., Kubová J. Determination of trace amounts of gold in acidattacked environmental samples by atomic absorption spectrometry with electrothermal atomization after preconcentration. Anal Bioanal Chem. 2004. No 1. P. 60-65.

7. Kryazhov A., Panova S., Kolpakova N., Pshenichkin A. Determination of $\mathrm{Au}, \mathrm{Pb}, \mathrm{Ni}$ and $\mathrm{Co}$ in Mineral Raw Materials by Atomic Absorption Spectroscopy with Graphite Furnace. Procedia Chem. 2014. No 10. P. 437-440.

8. Balcerzak M., Kosiorek A., Swiecicka E. Morin as a spectrophotometric reagent for Au. J. Anal. Chem. 2006. V. 61. P. 119-23.

9. El-Zawawy F.M., El-Shahat M.F., Mohamed A.A. Spectrophotometric determination of silver and $\mathrm{Au}$ with 5-(2,4-dihydroxyben zylidene)rhodanine and cationic surfactants. Analyst. 1995. V. 120. P. 549-54. 
10. Fujita Y., Mori I. and Matsuo T. Spectrophotometric determinationof $\mathrm{Au}(\mathrm{III})$ by an association complex formation between Au thiamine and phloxine. Anal. Sci. 1999. V. 15. P. 1009-12.

11. Gangadharappa M., Reddy P.R., Reddy V.R. and Reddy S. Direct spectrophotometric determination of $\mathrm{Au}(\mathrm{III})$ using 2'-aminoacetophenone isonicotinoyl hydrazone (2-AAINH). J. Indian Chem. Soc. 2004. V. 81. P. 525-7.

12. Rubina M., Jamaluddin A., Najma M., Khan H. A simple and selective spectrophotometric method for the determination of trace gold in real, environmental, biological, geological and soil samples using bis(salicylaldehyde) orthophenylenediamine. Anal. Chem. Insights. 2008. V. 3. P. 75-90.

13. Gambarov D.G. Novyi class fotometricheskikh reagentov - azosoedinenii na osnove pirogallola. Dis... dok. him. nauk. M.: MGU. 1984. S. 380.

14. Bulatov M.I. Kalinkin N.P. Prakticheskoe rukovodstvo po fotometricheskim metodam ana-liza. L.: Himiia. 1986. $432 \mathrm{~s}$.

\section{YENI SADӘ VӘ SÜRӘTLİ SPEKTROFOTOMETRIK ÜSULLARLA QIZILIN(III) 2,2', 3,4- TETRAHIDROKSİ-3'-SULFO-5'-XLORAZOBENZOL ILD KATION TIP SəTHI-AKTIV MADDӘLӘR IŞTIRAKINDA TOYINII \\ P.R.Məmmədov}

Q1zıl(III) 2,2',3,4-tetrahidroksi-3'-sulfo-5'-xlorazobenzol (TSXAB) ilə pH 5-6 turşuluqlu mühitdə sürətlə reaksiyaya girərək qəhvəyi-sarı rəngli kompleks və $\mathrm{pH}$ 5-6 turşuluqlu mühitdə kation tip səthi aktiv maddələr- cetilpiridin xlorid $(\mathrm{CPCl})$, cetilpiridin bromid $(\mathrm{CPBr})$ və cetiltrimetilammonium bromid (CTMABr) iştirakında isə qəhvəyi rəngli komplekslər əmələ gətirir. Au(III) - TSXAB sisteminin işıq udma spektrində maksimum 490 nm-də və molyar udma əmsallı 2.3 $10^{4} \mathrm{l} \mathrm{mol}^{-1} \mathrm{sm}^{-1}$ müşahidə olunur. Au(III)-TSXAB-CPCl, Au(III)-TSXAB-CPBr və Au(III)-TSXABCTMABr TSXAB sistemlərinin işıq udma spektrlərində maksimumlar 520, 520 və $540 \mathrm{~nm}$ dalğa uzunluqlarında müşahidə olunur və molyar udma əmsalları isə uyğun olaraq $3.78 \cdot 10^{4}, 3.67 \cdot 10^{4}$ and $3.81 \cdot 10^{4} 1 \mathrm{~mol}^{-1} \mathrm{sm}^{-1}$ qiymətlər alır. Optiki sıxlığın xəttiliyi Au(III) üçün 0.584-5.61 mkg/ml miqdarında Au(III)-TSXAB sistemində və 0.428-6.362 mkg/ml, 0.435-6.221 mkg/ml, 0.436-6.832 mkg/ml miqdarlarında isə uyğun olaraq Au(III)-TSXAB-CPCl, Au(III)-TSXAB- və $\mathrm{Au}(\mathrm{III})-\mathrm{TSXAB}-\mathrm{CTMABr}$ sistemlərində olur. Sendel həssaslığı Au(III) üçün Au(III)-TSXAB sistemində $7 \mathrm{mkg} \mathrm{cm}^{-2}$ və $\mathrm{Au}(\mathrm{III})-\mathrm{TSXAB}-\mathrm{CPCl}, \mathrm{Au}(\mathrm{III})-\mathrm{TSXAB}-\mathrm{CPBr}$ və Au(III)-TSXAB-CTMABr TSXAB sistemlərində isə 5, 6, $5 \mathrm{mkg} / \mathrm{cm}$ müəyyən edilmişdi. Təklif olunan metodlar qızılin (III) bir neçə sintetik qarışıqlarda təyinində uğurla tətbiq olunmuşdu. Nisbi standart kənara çixma Au(III) üçün (0-2.0)\% olmağı, bu üsulların yüksək dəqiqliyinin və təkrarlığının olduğunu göstərir. Alınan nəticələr sintetik qarışıq nümunələrinin induktiv əlaqəli plazma optik emissiya spektrometriyası üsulu ilə analizinin nəticələri ilə müqayisə edilmişdi.

Açar sözlor: spektrofotometrik, Au(III), toyin, 2,2',3,4-tetrahidroksi-3'-sulfo-5'-klorazobenzen, kation tip sathi-aktiv maddalor.

\section{НОВЫЙ ПРОСТОЙ И БЫСТРЫЙ СПЕКТРОФОТОМЕТРИЧЕСКИЙ МЕТОД ОПРЕДЕЛЕНИЯ СЛЕДОВЫХ КОЛИЧЕСТВ ЗОЛОТО (III) С ИСПОЛЬЗОВАНИЕМ 2, 2',3,4-ТЕТРАГИДРОКСИ-3'- СУЛЬФО-5'-ХЛОРАЗОБЕНЗЕОЛА В ПРИСУТСТВИИ КАТИОННЫХ ПОВЕРХНОСТНО-АКТИВНЫХ ВЕЩЕСТВ}

\section{П.Р.Мамедов}

Показано, что золото(III) с 2,2',3,4-тетрагидрокси-3'-сульфо-5'-хлоразобензолом (ТСХАБ) быстро реагирует в кислой среде при рН 5-6 с образованием коричневато-желтого комплекса и при рН 4-5 с образованием коричневатых комплексов в присутствии катионных поверхностно-активных веществ - хлорида цетилпиридиния (ЦПCl), бромида цетилпиридиния (ЦПВr) и бромида цетилтриметиламмония (ЦТМАВr). Спектры поглощения $\mathrm{Au}(\mathrm{III})-\mathrm{TCXАБ} \mathrm{представляют} \mathrm{собой} \mathrm{кривую} \mathrm{с} \mathrm{максимальным} \mathrm{свето} \mathrm{поглощением} \mathrm{при} 490$ нм и молярным коэффициентом поглощения 2,3 $10^{4}$ моль $^{-1} \mathrm{~cm}^{-1}$ в водных средах. Спектры поглощения систем Аu(III)-TCXАБ$\mathrm{CPCl}, \mathrm{Au}(\mathrm{III})-\mathrm{TCXАБ-ЦПВr} \mathrm{и} \mathrm{Аu(III)-ТСХАБ-ЦТМАВr} \mathrm{представляют} \mathrm{собой} \mathrm{кривую} \mathrm{с} \mathrm{максимальными} \mathrm{свето}$ поглощением при 520, 520 и 540 нм. и молярные коэффициенты поглощения составляют $3.7810^{4}, 3.6710^{4}$ и $3.8110^{4}$ моль $^{-1} \mathrm{~cm}^{-1}$ соответственно. Подчиняемость закону Бера Аu(III) в двойной системе Аu(III)-TCXАБ соблюдалось в пределах 0.584-5.61 мкг/мл, а в тройных системах Аu(III)-ТСХАБ-ЦПСl, Аu(III)-ТСХАБ-ЦПВr, $\mathrm{Au}(\mathrm{III})-\mathrm{TСХАБ-ЦТМАВr-} \mathrm{в} \mathrm{пределах} \mathrm{0.428-6.362,} \mathrm{0.435-6.221} \mathrm{и} \mathrm{0.436-6.832} \mathrm{мкг} \mathrm{мл}{ }^{-1}$ соответственно. Чувствительность Сэнделла для Аu(III) составила 7 мкг/см в системе Аu(III)-TCXА, и 5, 6, 5 мкг/см в системах Аu(III)ТСХАБ-ЦПСl, Аu(III)-ТСХАБ-ЦПВr и Аu(III)-СХАБ-ЦТМАВr. Предложенные методы были успешно использованы при определении Аu(III) в нескольких искусственных смесях. Относительное стандартное отклонение составляло (0-2.0)\% для Аu(III), что свидетельствует о высокой точности и воспроизводимости этих методов. Полученные результаты хорошо согласуются с образцами искусственной смеси, проанализированными методом оптической эмиссионной спектрометрии с индуктивно связанной плазмой.

Ключевые слова: спектрофотометрический, Аи(III), определение, 2,2',3,4-тетрагидрокси-3'-сульфо-5'-хлоразобензол, катионные поверхностно-активные вещества. 